\title{
INITIATION ON ECOSYSTEM APPROACH TO FISHERIES MANAGEMENT (EAFM): CASE STUDY ON TARAKAN FISHERIES
}

\author{
Andhika Prima Prasetyo', Duto Nugroho', Wudianto', Hari Eko Irianto' and Purwanto² \\ ${ }^{1}$ Research Centre for Fisheries Management and Conservation, Jakarta \\ ${ }^{2}$ Indonesia Marine and Climate Support (IMACS), Jakarta \\ Received April 23-2014; Received in revised form October 29-2014; Accepted November 03-2014 \\ E-Mail: dhika_fishery@yahoo.com
}

\begin{abstract}
An EAFM from a global perspective is still moving towards on implementation. EAFM is based on conventional fisheries management but broadens the perspective beyond seeing a fishery as simply "fish in the sea, people in boats," beyond consideration only of commercially important species, and beyond management efforts directed solely at the harvesting process. This research aims to initiate implementing EAFM in Indonesia: case in Tarakan Fisheries, North Kalimantan Province. From the initiate implementation of EAFM, we found that the possibility to improve the performance on arrange fisheries management based on ecosystem approach. EAFM could be used as tools to confirm scientific findings and gathering initial information on fisheries. In the case, fisheries community in Tarakan was put human well-being as important point to determine fisheries management, rather than ecological well-being. To secure the fisheries the possible options would arrange accepted and adaptable policy on controlling fisheries i.e. temporary fishing closure in term of area and season.
\end{abstract}

\section{KEYWORDS: Uncertainty, FGD, IFM, EAFM, Tarakan fisheries}

\section{INTRODUCTION}

In 2003 COFI was stated to adopt the Ecosystem Approach to Fisheries (EAF) to assist implement the Code of Conduct for Responsible Fisheries, UNCLOS and the Convention on Biological Diversity (Fletcher \& Bianchi, 2014). The EAFM is holistic approach on fisheries management; deals with all the ecological consequences of fishing including recognize the social and economic implications and its management arrangements in order to ensure at both human and ecosystem well-being (Fletcher, 2008; Garcia \& Cochrane, 2005). Binding national instruments also stated the great relevance to EAF i.e. Law No. 45/ 2009 amending Law No. 31/2004 concerning Fishery article 3 which is state fisheries management conducted to ensure optimizing fish resources and secure human welfare. Consequently, Indonesia needs to initiate EAFM to provide improved knowledge and assessment how EAFM could/should be implemented within Indonesia fisheries.

Tarakan Fisheries, as one of fisheries within SuluSulawesi Marine Eco-region (SSME) was pointed as demonstration site through SCS-SFM Project (SuluCelebes Sea - Sustainable Fisheries Management Project) funded by GEF to learn how EAFM could support the fisheries by developing Integrated Fisheries Management Plan (IFMP). In Tarakan waters, many species were exploited by using historically various fishing gears by the history (i.e. trawlers, gillnetters, long liners and traps). Demersal fisheries including mainly shrimp and demersal fishes dominate Tarakan fisheries. Fishes are mostly caucht by using trawls and gillnets (Marine Affairs and Fisheries Service - Tarakan City/MAFS-TC, 2013). Fishing fleets in Tarakan fisheries are dominated by small-scale boats $(<5 \mathrm{GT})$, that condition made coastal resources have high fishing pressure. There is also an issue on habitat damage in that area (Environment Bureau - Tarakan City/EB-TC, 2010). Some studies show that several fish resources tend to be overfishing (Research Institute for Marine Fisheries/RIMF, 2012).

Considering complicated fishing activities in Tarakan water, integrated fisheries management plan should be taken on addressing fisheries problems. Integrated means put ecosystem as the main factor in order to ensure sustainability of ecosystem services that would be providing sustainable resources and secure coastal communities livelihood. The purpose of this work is to initiate the best management practices in Tarakan, East Kalimantan, Indonesia within "umbrella" of the Ecosystem Approach to Fisheries management (EAFM).

\section{MATERIALS AND METHODS Area of study}

The IFMP tried to develop management on the area of Tarakan waters. Tarakan city is located in North 
Kalimantan Province (Previously East Kalimantan; Law no. 20/2012 concerning Establishing North Kalimantan Province). The administration area approximately $657.33 \mathrm{~km}^{2}$, where consist of 250.80 $\mathrm{km}^{2}$ for land and $406.53 \mathrm{~km}^{2}$ for marine waters (Appendix 1).

\section{EAFM Framework}

As holistic approach, EAFM is required to consider not just bio-ecology, but also covers issues on fishers including social-economic and governance. The main goal of EAFM is to improve the governance's performance (Fletcher, 2008). EAFM also puts ecosystem as the basis of the approach, as we know ecosystems play an important role in human societies by providing services that directly or indirectly benefit humans (Fletcher, 2008).

FAO (2005) stated that there are five key principles addressed by EAF, as follows: (1) fisheries should be managed to limit their impact on the ecosystem to an acceptable level; (2) ecological relationships between species should be maintained; (3) management measures should be compatible across the entire distribution of the resource; (4) precaution in decision-making and action is needed because the knowledge on ecosystems is incomplete; and (5) governance should ensure both human and ecosystem well-being and equity.

EAFM planning process in this case was combined steps based on several guidelines i.e. FAO (2005), SPC (2010)and DFR-WWF-CCMRS (2011). There are seven identified steps on EAFM planning process i.e. high level policy goal, relevant objective, priority issues, operational objective, indicators and reference points, decision rule and monitoring and evaluation (FAO, 2005). The whole process need to ensure the strong engagement with relevant stakeholders (Pomeroy et al., 2013), including identifying the key person, arranging effective discussion and conducting broad and effective dissemination. The other crucial step on EAFM is the development of indicators and reference points; on EAFM indicators it was divided into three main elements $(F A O, 2005)$ from ecological and human components i.e. ecological assessments, socio-economic wellbeing outcomes and ability to achieve (Fletcher, 2008), it was derived into six indicator's domain (DFR-WWF-CCMRS, 2011) i.e. fish resources, habitat and ecosystem, fishing technique, socio, economic and governance. Developing indicators will be fitted to the priority issues that already identified during Focus Group Discussion.

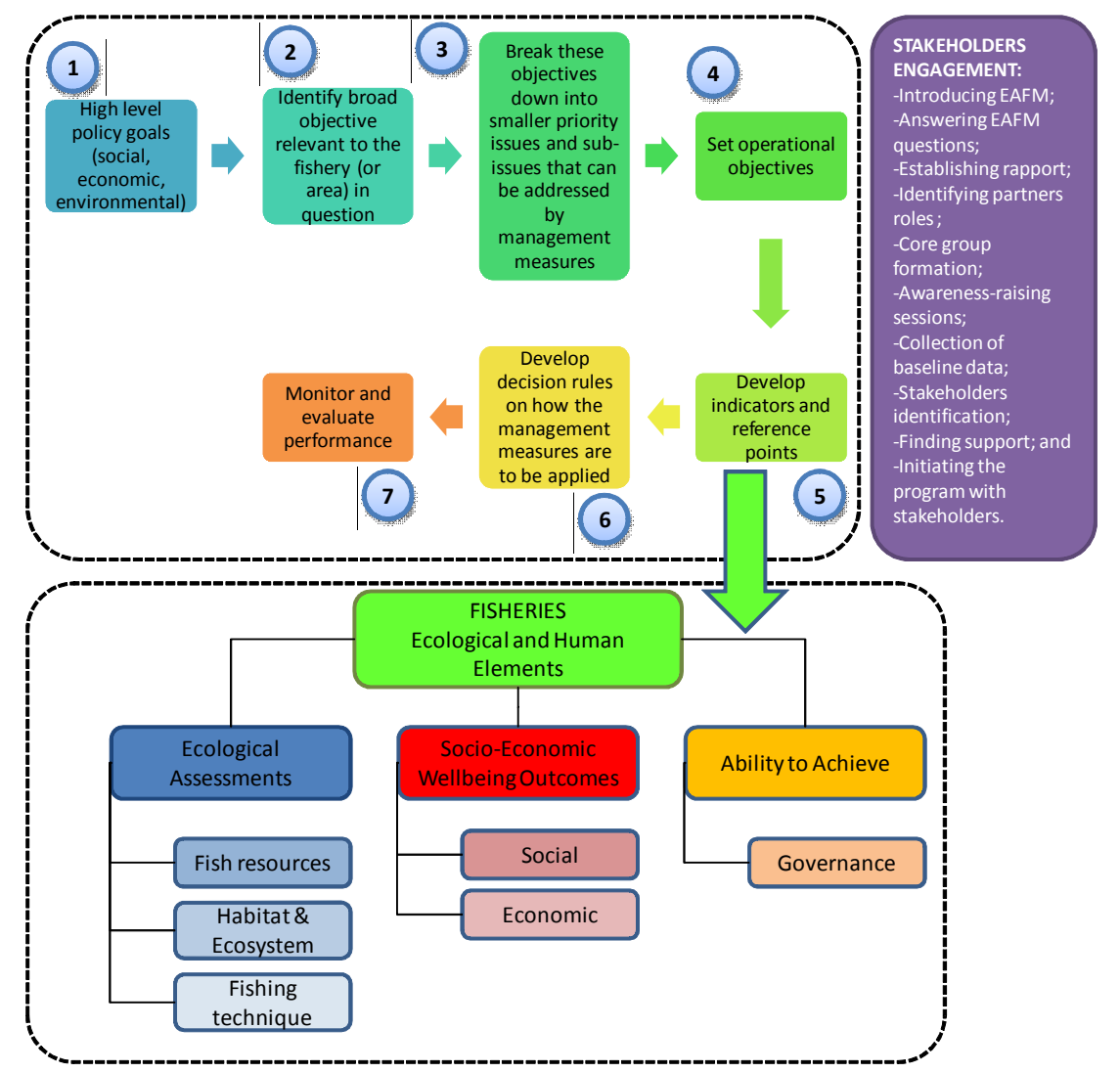

Figure 1. EAFM planning process (adapted from FAO, 2005; Fletcher, 2005, Pomeroy et al., 2010 and DFRWWF-CCMRS, 2011). 


\section{FOCUS GROUP DISCUSSION (FGD)}

In order to gathering issues and participatory of stakeholders which presented by government, university, fishers and non-governmental organization, some meetings of Focus Group Discussion (FGD) were held:

1. First FGD - 8 November 2013 in Padma Hotel, Tarakan - East Kalimantan. The output was the formulating of prioritized issues and propose management actions;

2. Second FGD - 19 February 2014 in MAFS Tarakan City, Tarakan - East Kalimantan. The output was the formulating of prioritized doable management actions and legal consultation;

3. Third FGD - 15 April 2014 in North Tarakan District, Tarakan - East Kalimantan. The output was the agreement with fishers on fishing closure, and limitating fishing capacity to ensure sustainability of bombay duck (Harpodon nehereus) fisheries in North Tarakan waters.

Prioritizing issues was conducted by scoring; those issues were assessing to gather the risk level from impact and likelihood value. Impact was described as consequence of the issues on biomass. Each issue was ranked by its impact and possibility and risk (value of impact and possibility). Impact was described as consequence of the issues on biomass status. An estimate of the impact level for each issue was made and scored from 1-4 based on scoring criteria, with 1 being minor and 4 being extreme (Modified from PIRSA (2013) Appendix 2).

The likelihood of that consequence occurring was scored from 1-4, with 1 being remote and 4 being likely (Appendix 2). This was based on a judgment about the probability of the events, or chain of events, occurring that could result in a particular adverse consequence. This judgment about conditional probability was again based on the collective experience and knowledge of workshop participants (PIRSA, 2013).

\section{RESULTS AND DISCUSSION}

\section{Result \\ General Condition}

Tarakan is an island city located on the north area of East Kalimantan Province, and has been declared as part of new province, North Kalimantan Province since 2012. The administration area is approximately $657.33 \mathrm{~km}^{2}$ consisting of $250.80 \mathrm{~km}^{2}$ of land and 406.53 $\mathrm{km}^{2}$ of marine waters. In order to increase their welfare, many fishers altered their livelihood from fishing to seaweed farming. It was introduced in 2008 by collaborating program between Local Marine and Fisheries Service and IndonesianInstitute of Sciences (LIPI) on trial program of seaweed farming. For one harvest period, they could get 3 million rupiahs as net income. Besides that, they do not depend on fishing season. The condition will be easily found in Pantai Amal Sub-district, East Tarakan District, where fisher of tidal trap ("tugu") shifts their livelihood.

As consequences of narrow waters area and fisheries structure which dominated by small-scale fisheries, coastal fish resources was utilized in high pressure. In fact, the most utilizing waters is located in eastern part or Tarakan, recently sea-weed farming become popular and is rapidly developing. This condition causes the fishing area of several fishing gear was occupied. In fact, sea-weed farming does not only secure fish resources from fishing, but also is unintended to inviting of other fishes that utilized as recreational fishing. The potency of conflict will be rising, if appropriate management action is not as soon as applied.

\section{Policy based EAFM}

The first step on following EAFM process is to identify high level policy goal. In order to set the goal, we are adapted Millennium Development Goal of Republic of Indonesia 2011, i.e. (1) Pro-poor, (2) Progrowth, (3) Pro-job, and (4) Pro-environment. Furthermore, that policy goal was mentioned to Vision of Ministry of Marine Affairs and Fisheries (MMAF) i.e. "Competitive and sustainable development on marine and fisheries for society welfare". The vision shows us that MMAF program is derived to increase the competitive and sustainable development on marine and fisheries sector; in order to secure marine and fisheries community welfare. In 2014, Government Performance Plan (GPP/Rencana Kinerja Pemerintah) mostly has similar vision i.e. "Stabilizing National Economic for Improving Equitable Society Welfare" as legalized by Presidential Decree No. 39 in 2013 concerning Government Performance Plan 2014.

Furthermore, to identify the prioritizing goal on fisheries management as mentioned on Regulations No. 45 in 2009 changed on Regulation No. 31 in 2004 article 3 concerning Fisheries, forum has agreed on how fisheries management objective prioritizing (Table 1).Forum has agreed that the highest priority of fisheries management is to improve the living conditions of small-scale fishermen and fish farmers rather than to increase the government's revenues and foreign exchange. As consequences, government of 
Tarakan should be accommodating community to secure their livelihood as fishers or fish farmers. Sustainable developing i.e. to achieve the optimum utilization of fishery resources, area for fish culture resources environment and to optimize the management of fishery resources closely related to ecological sustainability is medium priority. SPC
(2010) stated that ecological and human wellbeing trade-off as the most serious decision problem on fisheries management. The policy maker should choose short-term or long-term; productivity or biodiversity; quantity or quality; economic efficiency; growth or survival; etc.

Table 1. Prioritizing of fisheries management objective

\begin{tabular}{|c|l|c|}
\hline No. & \multicolumn{1}{|c|}{ Objective } & Priority \\
\hline 1 & to improve the living conditions of small-scale fishermen and fish farmers & 9 \\
\hline 2 & to increase the government's revenues and foreign exchange & 1 \\
\hline 3 & to spur the expansion of job opportunities & 4 \\
\hline 4 & to increase the supply and consumption of fish which is rich in protein sources & 3 \\
\hline 5 & to optimize the management of fishery resources & 5 \\
\hline 6 & to increase the productivity, quality, added value, and competitiveness & 8 \\
\hline 7 & to increase the supply of raw materials for fish processing Industry & 2 \\
\hline 8 & $\begin{array}{l}\text { to achieve the optimum utilization of fishery resources, area for fish culture } \\
\text { resources environment }\end{array}$ & 6 \\
\hline 9 & $\begin{array}{l}\text { to ensure the conversation of fishery resources, areas for fish culture, and spatial } \\
\text { management }\end{array}$ & 7 \\
\hline
\end{tabular}

Comments: 1 (less) -9 (high)

Table 2. Identification and prioritizing of actual issues on Tarakan fisheries

\begin{tabular}{|c|c|c|c|c|c|c|}
\hline Aspect & Component & Issue & Impact & Likelihood & $\begin{array}{l}\text { Risk (Impact } \\
\text { x Likelihood }\end{array}$ & Remark \\
\hline \multirow[t]{7}{*}{$\begin{array}{l}\text { Ecological } \\
\text { aspect }\end{array}$} & \multirow[t]{2}{*}{ Fish resources } & $\begin{array}{l}\text { Unintended catch of } \\
\text { juveniles }\end{array}$ & 4 & 4 & 16 & $\begin{array}{l}\text { Extremely } \\
\text { important }\end{array}$ \\
\hline & & Decreasing fish size & 2 & 1 & 2 & $\begin{array}{l}\text { Less } \\
\text { important }\end{array}$ \\
\hline & \multirow[t]{3}{*}{ Habitat } & $\begin{array}{l}\text { Unsustainable } \\
\text { aquaculture practices }\end{array}$ & 3 & 4 & 12 & $\begin{array}{l}\text { Very } \\
\text { important }\end{array}$ \\
\hline & & Mangrove conversion & 3 & 2 & 6 & Important \\
\hline & & $\begin{array}{l}\text { Marine pollution } \\
\text { (domestic waste, fuel, } \\
\text { etc) }\end{array}$ & 4 & 4 & 16 & $\begin{array}{l}\text { Extremely } \\
\text { important }\end{array}$ \\
\hline & \multirow[t]{2}{*}{$\begin{array}{l}\text { Fishing } \\
\text { technique }\end{array}$} & $\begin{array}{l}\text { Overlapping fishing } \\
\text { ground }\end{array}$ & 1 & 1 & 1 & $\begin{array}{l}\text { Less } \\
\text { important }\end{array}$ \\
\hline & & $\begin{array}{l}\text { Inappropriate fishing } \\
\text { gear }\end{array}$ & 3 & 4 & 12 & $\begin{array}{l}\text { Very } \\
\text { important }\end{array}$ \\
\hline \multirow{3}{*}{$\begin{array}{l}\text { Social- } \\
\text { economic } \\
\text { aspect }\end{array}$} & \multirow[t]{2}{*}{ Social } & $\begin{array}{l}\text { Competition with foreign } \\
\text { fishers }\end{array}$ & 4 & 3 & 12 & $\begin{array}{l}\text { Very } \\
\text { important }\end{array}$ \\
\hline & & $\begin{array}{l}\text { Conflict on resource } \\
\text { utilization }\end{array}$ & 3 & 2 & 6 & Important \\
\hline & Economic & Low value added & 3 & 3 & 9 & $\begin{array}{l}\text { Very } \\
\text { important }\end{array}$ \\
\hline \multirow[t]{4}{*}{$\begin{array}{l}\text { Governance } \\
\text { aspect }\end{array}$} & \multirow[t]{3}{*}{ Management } & $\begin{array}{l}\text { Unsystematic data } \\
\text { recording }\end{array}$ & 4 & 4 & 16 & $\begin{array}{l}\text { Extremely } \\
\text { important }\end{array}$ \\
\hline & & $\begin{array}{l}\text { Unsystematic fishing } \\
\text { registration }\end{array}$ & 3 & 3 & 9 & $\begin{array}{l}\text { Very } \\
\text { important }\end{array}$ \\
\hline & & $\begin{array}{l}\text { Limited capacity on law } \\
\text { enforcement }\end{array}$ & 3 & 4 & 12 & $\begin{array}{l}\text { Very } \\
\text { important }\end{array}$ \\
\hline & Consultation & $\begin{array}{l}\text { Limited discussion } \\
\text { forum }\end{array}$ & 3 & 1 & 3 & $\begin{array}{l}\text { Less } \\
\text { important }\end{array}$ \\
\hline
\end{tabular}

Comment: Score of importance (1-16)

\begin{tabular}{|c|l|l|l|}
\hline Level & \multicolumn{1}{|c|}{ Description } & Score & Color code \\
\hline 4 & Extremely important & $13-16$ & \\
\hline 3 & Very important & $9-12$ & \\
\hline 2 & Important & $5-8$ & \\
\hline 1 & Less important & $1-4$ & \\
\hline
\end{tabular}

The next step of EAFM process is to identify relevant issues in Tarakan fisheries. The information that provided by research, literate and interview there are several actual issues based on three main aspects i.e. ecological, social-economic and governance aspects. The issues of Tarakan fisheries are unintended catch of juveniles, decreasing of fish size, unsustainable aquaculture practices, mangrove 
conversion, marine pollution (domestic waste, fuel, etc), over-lapping fishing ground, inappropriate fishing gear, competition with foreign fishers, conflict on resource utilization, low value added, unsystematic data recording, unsystematic fishing registration, limited capacity on law enforcement, and limited discussion forum.

The scoring will provide prioritizing issues which need to under taken; there are nine issues that have high priority 9-16 (very important - extremely important) i.e. unintended catch of juveniles, unsustainable aquaculture practices, marine debris (domestic waste, fuel, etc), inappropriate fishing gears, competition with foreign fishers, low value added, unsystematic data collection, unsystematic fishing registration and limited capacity on law enforcement (Table 2).

\section{Formulating of Management Action}

Agreed priority issues need to be companied by management actions to minimize the impact of those issues to biomass. Overall, there are 24 management actions which are proposed by the participants i.e. mesh size regulation; processing on unintended catch of juveniles; fishing closure in the downstream and estuary (suspected as nursery ground); limitation fishing area; restocking; increasing fishing, processing and human capacity; mangrove re-plantation; revitalization of unproductive fishpond; development of sylvo-fishery; banning aquaculture practice which using pesticide and hazardous chemical material; increasing "green line" of mangrove forest; proposing local regulation on marine pollution; decreasing marine debris; providing disposal facilities; effective dissemination on regulations; increasing surveillance activities; improving management on market chain; improving strategy on data collection; improving human capacity in data collection; there is a need to legalize collector/middle-man (export requirement from EU); cooperation between Community Base Surveillance (POKMASWAS) and Local Marine and Fisheries Services in data collection. It is also need to be followed up by legalize; improving Fish Auction Function; increasing surveillance activities; propose Vessel ID (PAS Kecil) as requirement to get subsidize fuel; and improving law enforcement through reward and punishment (Figure 2 \& Appendix 3 ).

\begin{tabular}{|c|c|c|c|}
\hline \multirow{2}{*}{ Ecological } & Indicator & $\begin{array}{c}\text { Benchmark / Reference } \\
\text { Point }\end{array}$ & Management Action \\
\hline & $\begin{array}{l}\text { Lc }(20.8 \mathrm{cmTL})<\mathrm{Lm} \\
(25 \mathrm{cmTL})\end{array}$ & $\begin{array}{l}\text { Lc } \geq \text { Lm; Lc } 10 \% \text { high } \\
\text { than Lm }\end{array}$ & Temporary fishing closure (area and season) \\
\hline \multirow{2}{*}{$\begin{array}{l}\text { Unintended catch of juveniles; } \\
\text { Unsustainable aquaculture practices; } \\
\text { Marine pollution (domestic waste, fuel, etc); } \\
\text { Inappropriate fishing gear; }\end{array}$} & \begin{tabular}{|l} 
- Mangrove \\
deforestration \\
- Using pesticide and \\
fertilizer \\
- Green belt $<5 \mathrm{~m}$ \\
\end{tabular} & \begin{tabular}{|l|} 
- Decreasing pesticide \\
and fertilizer \\
- Increasing green belt $>$ \\
$5 \mathrm{~m}$
\end{tabular} & \begin{tabular}{|l} 
- Mangrove re-plantation \\
- Development of sylvo-fishery \\
- Banning aquaculture practice which using pesticide and \\
hazardous chemical material
\end{tabular} \\
\hline & $\begin{array}{l}\text { - PAH pollution } \\
\text { - Domestic waste }\end{array}$ & $\begin{array}{l}\text { - Decresing marine } \\
\text { debris }\end{array}$ & $\begin{array}{l}\text { - Proposing Local Regulation on marine pollution } \\
\text { - Providing disposal facilities } \\
\text { - Effective dissemination on regulations } \\
\end{array}$ \\
\hline \multirow[b]{2}{*}{ Socio-economic } & $\begin{array}{l}\text { Fishing in forbidden / } \\
\text { vulnerable area }\end{array}$ & \begin{tabular}{|l|} 
- Decresing \\
inappropriate fishing \\
practice
\end{tabular} & \\
\hline & $\begin{array}{l}\text { Incresing number of } \\
\text { foreign fishers }\end{array}$ & \begin{tabular}{|l|} 
- Incresing number of \\
local fishers that access \\
frontline waters (INKA \\
MINA)
\end{tabular} & - Increasing human and fishing capacity \\
\hline $\begin{array}{l}\text { Competition with foreign fishers; } \\
\text { Low value added; }\end{array}$ & $\begin{array}{l}\text { Low value added of } \\
\text { fisheries product }\end{array}$ & $\begin{array}{l}\text { Incresing value added of } \\
\text { fisheries product }\end{array}$ & $\begin{array}{l}\text { - Increasing fishing, processing and human capacity } \\
\text { - Improving management on market chain }\end{array}$ \\
\hline \multirow[t]{2}{*}{ Governance } & $\begin{array}{l}\text { Unsystematic data } \\
\text { recording }\end{array}$ & $\begin{array}{l}\text { Incresing data recording } \\
\text { scheme }\end{array}$ & $\begin{array}{l}\text { - Effective dissemination on regulations } \\
\text { - Improving strategy on data collection } \\
\text { - Improving human capacity in data collection } \\
\text { - Cooperation between Community Base Surveillance } \\
\text { (POKMASWAS) } \\
\text { - Improving Fish Auction Function }\end{array}$ \\
\hline & $\begin{array}{l}\text { Unsystematic fishing } \\
\text { registration }\end{array}$ & \begin{tabular}{|l|} 
Improving fishing \\
registration process
\end{tabular} & $\begin{array}{l}\text { - Effective dissemination on regulations } \\
\text { - Propose Vessel ID (PAS Kecil) as requirement to get } \\
\text { subsidize fuel }\end{array}$ \\
\hline $\begin{array}{l}\text { Unsystematic data recording; } \\
\text { Unsystematic fishing registration; and } \\
\text { Limited capacity on law enforcement. }\end{array}$ & $\begin{array}{l}\text { Limited capacity on law } \\
\text { enforcement }\end{array}$ & $\begin{array}{l}\text { Increasing capacity on } \\
\text { law enforcement }\end{array}$ & $\begin{array}{l}\text { - Effective dissemination on regulations } \\
\text { - Improving law enforcement through reward and } \\
\text { punishment }\end{array}$ \\
\hline
\end{tabular}

Figure 2. Developing indicators. 


\section{Discussion}

Pomeroy et al. (2013) stated that the difference between conventional management and EAFM; EAFM is based on conventional fisheries management but broadens the perspective beyond seeing a fishery as simply "fish in the sea, people in boats," beyond consideration only of commercially important species, and beyond management efforts directed solely at the harvesting process. In fact there is no fisheries management applied within Indonesian waters, so EAFM will provide important information on how we could decrease uncertainty on existing status of fisheries. An EAFM from a global perspective is still moving towards on implementation, although in few countries may already be quite advanced. It represents the onlyopportunity for fisheries to become responsible and sustainable, but its implementation involves many challenges for the stakeholders (Garcia \& Cochrane, 2005). The main key success on implementing EAFM is commitment among stakeholders on how they perception to manage their fish resources to ensure their livelihood. Feedback and adaptation are also important to review the management process.

What we can learn from initiating EAFM in Tarakan fisheries is scientific information in order to back up/ drive stakeholders perception. Identify legal aspect to support management framework should be understanding in better way, so we can get better support from policy maker to make sure the consensus would be adapted. Identify key person to involve in discussion is also important, so we could get better view/understanding the fisheries. Besides that, the appropriate key person could also play role important as "messenger" to their community to deliver our sustainable missions. The last, but not the least is the interactive facilitators which have important role to running the intensive discussion with fun way.

\section{CONCLUSIONS}

From the initiate implementation of EAFM, we found that possibility to improve the performance on arrange fisheries management based on ecosystem approach. EAFM could be used as tools to confirm scientific findings and gathering initial information on fisheries. In this case, fishery community in Tarakanis to put human well-being as important point to determine fisheries management, rather than ecological well-being. The possible options to secure the fisheries are by arrange the accepted and adaptable policy on controlling fisheries i.e. temporary fishing closure in term of area and season.

\section{ACKNOWLEDGEMENTS}

The participating partners of UNOPS Project, "The Implementation of Tarakan East Kalimantan Demonstration Site of The SCS-SFMP'funded by GEF; implement and executing by UNDP and UNOPS respectively. We wish to thank the many people who provide information for the field investigations. This includes staff of Research Institute for Marine Fisheries (RIMF), Government Representative, and Port authorities, as well as fisher groups.

\section{REFERENCES}

DFR-WWF-CCMRS. 2011. Performance Indicators of Ecosystem Approach to Fisheries Management and Preliminary Assessment to Indonesian Fishery Management Areas. 39 pp.

Environmental Bureau-Tarakan City. 2010. Environment Status of Tarakan 2010 (Status LingkunganHidup Daerah Kota TarakanTahun 2010). Tarakan : District Environmental Management Office. [In Indonesia].

FAO. 2005. Putting into practice the ecosystem approach to fisheries. Rome, FAO. 2005. 76p.

Fletcher, W. J. 2008. A Guide to Implementing an Ecosystem Approach to Fisheries Management (EAFM) for the tuna fisheries of the Western and Central Pacific Region.Forum Fisheries Agency, Honiara, Solomon Islands. Version 5 March 2008. 70pp.

Fletcher, W. J \& G. Bianchi. 2014. The FAO - EAF toolbox: Making the ecosystem approach accessible to all fisheries. Ocean \& Coastal Management Volume 90, March 2014. p 20-26.

Garcia, S. M \& K. L. Cochrane,. 2005. Ecosystem approach to fisheries: a review of implementation guidelines. ICES Journal of Marine Science, 62: 311-318.

Marine Affairs \& Fisheries Services of Tarakan City (MAFS-TC). 2014 (In Indonesia). Fisheries Statistics 2013. Tarakan: Dinas Kelautandan Perikanan Kota Tarakan. 134 pp.

Mooney, H. A \& P. R. Ehrlich. 1997. Ecosystem services: a fragmentary history. In G. C. Daily, ed. Nature's Services: societal dependence on natural ecosystems, pp. 11-19. Island Press, Washington, DC. 342 pp. 
PIRSA (Primary Industries and Region South Australia). 2013. ESD risk assessment of South Australia's Sardine Fishery. 156 pp.

Pomeroy, R., R. Brainard, M. Moews, A. Heenan, J. Shackeroff \& N. Armada. 2013. Coral Triangle Regional Ecosystem Approach to Fisheries Management (EAFM) Guidelines. Publication. Honolulu, Hawaii: The USAID Coral Triangle Support Partnership. 134 pp.
Research Institute for Marine Fisheries (RIMF). 2012. (In Indonesia). Annual Report: Study on demersal fish resources in 716 FMA-Sulawesi Sea and 712 FMA-Java Sea. [Unpublilshed]. Jakarta: Research Institute for Marine Fisheries. 228 pp.

SPC. 2010. A community-based ecosystem approach to fisheries management: guidelines for Pacific Island Countries /compiled by the Secretariat of the Pacific Community. 65 pp. 
Ind.Fish.Res.J. Vol.20 No.2 December 2014: 87-98

Appendix 1. Urban land use plan of Tarakan city (Agency for Regional Development of Tarakan, 2013).
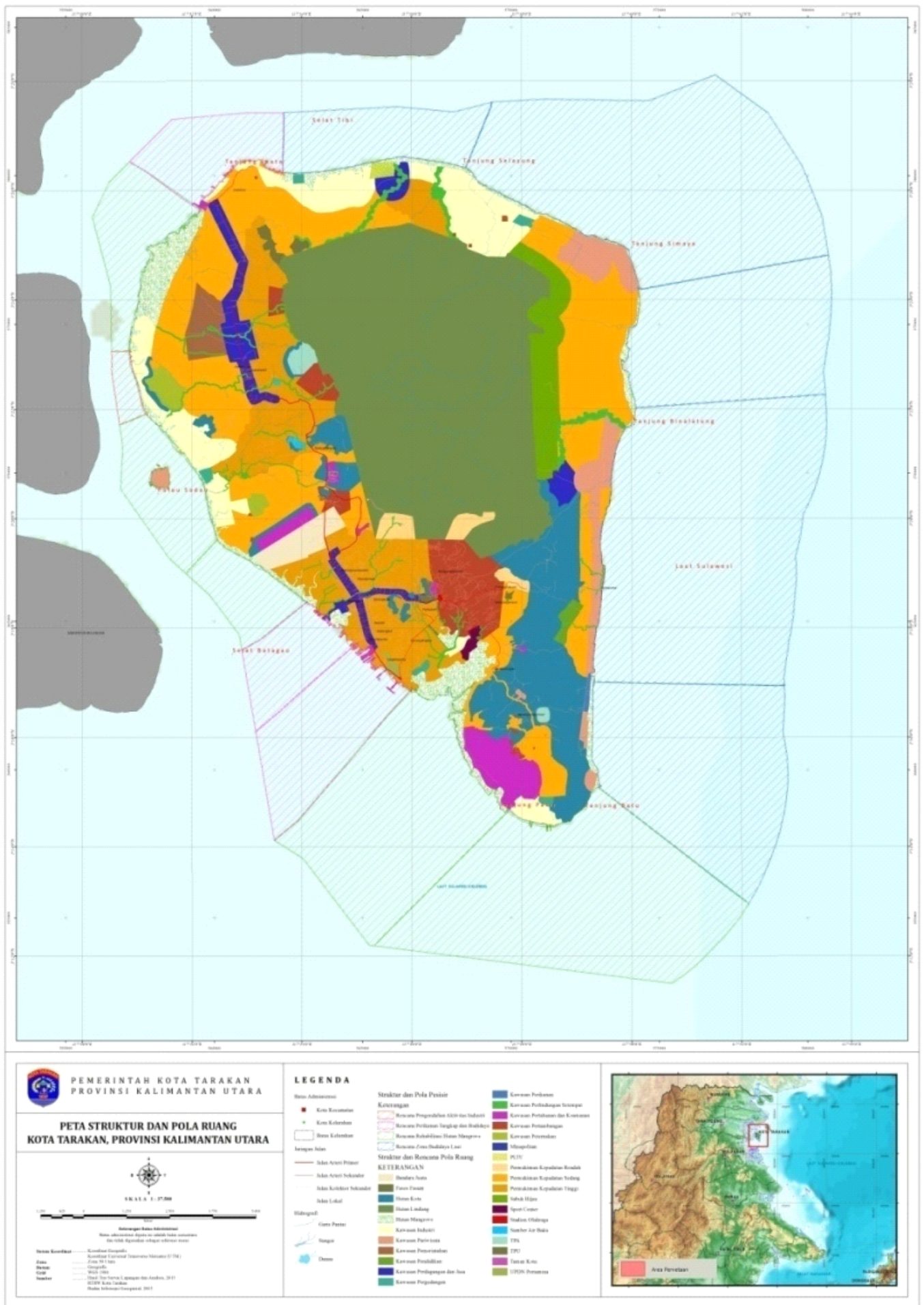
Appendix 2. Impact and likelihood level

\begin{tabular}{|c|c|}
\hline Level & Descriptor \\
\hline 1 (Minor) & $\begin{array}{l}\text { Either not detectable against background variability for this population; or if } \\
\text { detectable, minimal impact on population size and none on dynamics. } \\
\text { Exploited Stock Abundance Range } 100 \% \text { to } 70 \% \text { unfished levels }\end{array}$ \\
\hline 2 (Moderate) & $\begin{array}{l}\text { Fishery operating at, or close to, the exploitation rate that will deliver MSY. } \\
\text { Exploited Stock Abundance Range }<70 \% \text { to }>\text { Bmsy }\end{array}$ \\
\hline 3 (Major) & $\begin{array}{l}\text { Stock has been reduced to levels below MSY and may also be getting into the } \\
\text { range where recruitment overfishing may occur. } \\
\text { Exploited Stock Abundance Range }<\mathrm{B}_{\mathrm{MSY}} \text { to } 5 \%\end{array}$ \\
\hline 4 (Extreme) & $\begin{array}{l}\text { Stock size or significant species range contraction }>50 \% \text { have occurred and } \\
\text { recruitment levels reduced affecting future recruitment and their capacity to } \\
\text { increase from a depleted state (i.e. recruitment overfishing) } \\
\text { Exploited Stock Abundance Range Spawning biomass }<5 \%\end{array}$ \\
\hline
\end{tabular}


Appendix 3. Identification of management action on addressing prioritized issues

\begin{tabular}{|c|c|c|c|c|c|c|}
\hline Aspect & Component & Issues & Risk & Remarks & Management action & $\begin{array}{c}\text { Relevant } \\
\text { stakeholders }\end{array}$ \\
\hline \multirow[t]{4}{*}{$\begin{array}{l}\text { Ecological } \\
\text { aspect }\end{array}$} & $\begin{array}{l}\text { Fish } \\
\text { resources }\end{array}$ & $\begin{array}{l}\text { Unintended } \\
\text { catch of } \\
\text { juveniles }\end{array}$ & 16 & $\begin{array}{l}\text { Extremely } \\
\text { important }\end{array}$ & $\begin{array}{l}\text { - Mesh size } \\
\text { regulation } \\
\text { - Processing on } \\
\text { unintended catch } \\
\text { of juveniles } \\
\text { - Fishing closure in } \\
\text { the downstream } \\
\text { and estuary which } \\
\text { suspected as } \\
\text { nursery ground } \\
\text { - Limitation fishing } \\
\text { area } \\
\text { - Restocking } \\
\text { - Increasing fishing } \\
\text { capacity }\end{array}$ & $\begin{array}{l}\text { - Fishers } \\
\text { - Community } \\
\text { Base } \\
\text { Surveillance } \\
\text { (POKMASWAS) } \\
\text { - Local Marine } \\
\text { and Fisheries } \\
\text { Services (DKP) } \\
\text { - Research, } \\
\text { Empowerment, } \\
\text { Community } \\
\text { Services } \\
\text { Institute, } \\
\text { Borneo Tarakan } \\
\text { University } \\
\text { (LP3M-UBT) }\end{array}$ \\
\hline & Habitat & $\begin{array}{l}\text { Unsustainable } \\
\text { aquaculture } \\
\text { practices }\end{array}$ & 12 & $\begin{array}{l}\text { Very } \\
\text { important }\end{array}$ & $\begin{array}{l}\text { - Mangrove re- } \\
\text { plantation } \\
\text { - Revitalization of } \\
\text { unproductive } \\
\text { fishpond } \\
\text { - Development of } \\
\text { sylvo- fishery } \\
\text { - Banning } \\
\text { aquaculture } \\
\text { practice which } \\
\text { using pesticide and } \\
\text { hazardous } \\
\text { chemical material } \\
\text { - Increasing "green } \\
\text { line" of mangrove } \\
\text { forest }\end{array}$ & $\begin{array}{l}\text { - Fish farmer } \\
\text { - DKP } \\
\text { - Agency for } \\
\text { Environment } \\
\text { Management } \\
\text { (BPLH) } \\
\text { - Agency for } \\
\text { Planning and } \\
\text { Development } \\
\text { (BAPPEDA) } \\
\text { - LP3M-UBT }\end{array}$ \\
\hline & & $\begin{array}{l}\text { Marine debris } \\
\text { (domestic } \\
\text { waste, fuel, etc) }\end{array}$ & 16 & $\begin{array}{l}\text { Extremely } \\
\text { important }\end{array}$ & $\begin{array}{l}\text { - Proposing Local } \\
\text { Regulation on } \\
\text { marine pollution } \\
\text { - Decreasing marine } \\
\text { debris } \\
\text { - Providing disposal } \\
\text { facilities }\end{array}$ & $\begin{array}{l}\text { - Fishers } \\
\text { - POKMASWAS } \\
\text { - DKP } \\
\text { - BPLH } \\
\text { - Sanitation and } \\
\text { Landscape } \\
\text { Services } \\
\text { (DKPP) } \\
\text { - LP3M-UBT }\end{array}$ \\
\hline & $\begin{array}{l}\text { Fishing } \\
\text { technique }\end{array}$ & $\begin{array}{l}\text { Inappropriate } \\
\text { fishing gear }\end{array}$ & 12 & $\begin{array}{l}\text { Very } \\
\text { important }\end{array}$ & $\begin{array}{l}\text { - Disseminate } \\
\text { regulation } \\
\text { - Increasing } \\
\text { surveillance } \\
\text { activities } \\
\text { - Sanction }\end{array}$ & $\begin{array}{l}\text { - Fishers } \\
\text { - POKMASWAS } \\
\text { - DKP } \\
\text { - Directorate } \\
\text { General for } \\
\text { Marine and } \\
\text { Fisheries } \\
\text { Surveillance } \\
\text { (PSDKP) } \\
\text { - Fishing Gear } \\
\text { Development } \\
\text { Institute (BBPPI } \\
\text { Semarang) } \\
\text { - LP3M-UBT }\end{array}$ \\
\hline
\end{tabular}




\begin{tabular}{|c|c|c|c|c|c|c|}
\hline $\begin{array}{l}\text { Social- } \\
\text { economic } \\
\text { aspect }\end{array}$ & Economic & $\begin{array}{l}\text { Competition with } \\
\text { foreign fishers }\end{array}$ & 12 & $\begin{array}{l}\text { Very } \\
\text { important }\end{array}$ & $\begin{array}{l}\text { - Increasing fishing } \\
\text { capacity } \\
\text { - Increasing } \\
\text { surveillance } \\
\text { activities } \\
\text { - Increasing } \\
\text { processing } \\
\text { capacity } \\
\text { - Increasing } \\
\text { processing } \\
\text { technology } \\
\text { - Increasing human } \\
\text { capacity } \\
\text { - Improving } \\
\text { management on } \\
\text { market chain }\end{array}$ & $\begin{array}{l}\text { - Nelayan } \\
\text { - POKMASWAS } \\
\text { - DKP } \\
\text { - PSDKP } \\
\text { - Fishers } \\
\text { - Collector/ } \\
\text { Middle-man } \\
\text { - POKMASWAS } \\
\text { - DKP } \\
\text { - Research } \\
\text { Center for } \\
\text { Fisheries } \\
\text { Management } \\
\text { and } \\
\text { Conservation } \\
\text { (P4KSI) } \\
\text { - Research } \\
\text { Institute for } \\
\text { Biotechnology } \\
\text { and Post- } \\
\text { processing } \\
\text { Technology } \\
\text { (BBP4B) } \\
\text { - Agency for } \\
\text { Marine and } \\
\text { Fisheries } \\
\text { Extention } \\
\text { (BPSDM) } \\
\text { - Directorate } \\
\text { General for } \\
\text { Processing and } \\
\text { Marketing on } \\
\text { Fisheries } \\
\text { Product (P2HP) } \\
\text { - LP3M-UBT }\end{array}$ \\
\hline $\begin{array}{l}\text { Governanc } \\
\text { e aspect }\end{array}$ & Management & $\begin{array}{l}\text { Unsystematic } \\
\text { data collection }\end{array}$ & 16 & $\begin{array}{l}\text { Extremely } \\
\text { important }\end{array}$ & $\begin{array}{l}\text { - Improving strategy } \\
\text { on data collection } \\
\text { - Improving human } \\
\text { capacity in data } \\
\text { collection } \\
\text { - Reward and } \\
\text { punishment } \\
\text { - There is a need to } \\
\text { legalized } \\
\text { collector/middle- } \\
\text { man (export } \\
\text { requirement from } \\
\text { EU) } \\
\text { - Disseminate } \\
\text { "Travel } \\
\text { Letter/Letter of } \\
\text { Origin" } \\
\text { - Cooperation } \\
\text { between } \\
\text { Community Base } \\
\text { Surveillance } \\
\text { (POKMASWAS) } \\
\text { and Local Marine } \\
\text { and Fisheries } \\
\text { Services in data } \\
\text { collection. Need to } \\
\text { be followed up by } \\
\text { legalized. }\end{array}$ & $\begin{array}{l}\text { - Fishers } \\
\text { - POKMASWAS } \\
\text { - DKP } \\
\text { - P4KSI } \\
\text { - Directorate for } \\
\text { Fish Resources } \\
\text { (SDI-DJPT) } \\
\text { - BPSDM } \\
\text { - LP3M-UBT } \\
\text { - Collector/ } \\
\text { Middle-man } \\
\text { - Fish Quarantine } \\
\text { - BAPPEDA }\end{array}$ \\
\hline
\end{tabular}


Ind.Fish.Res.J. Vol.20 No.2 December 2014: 87-98

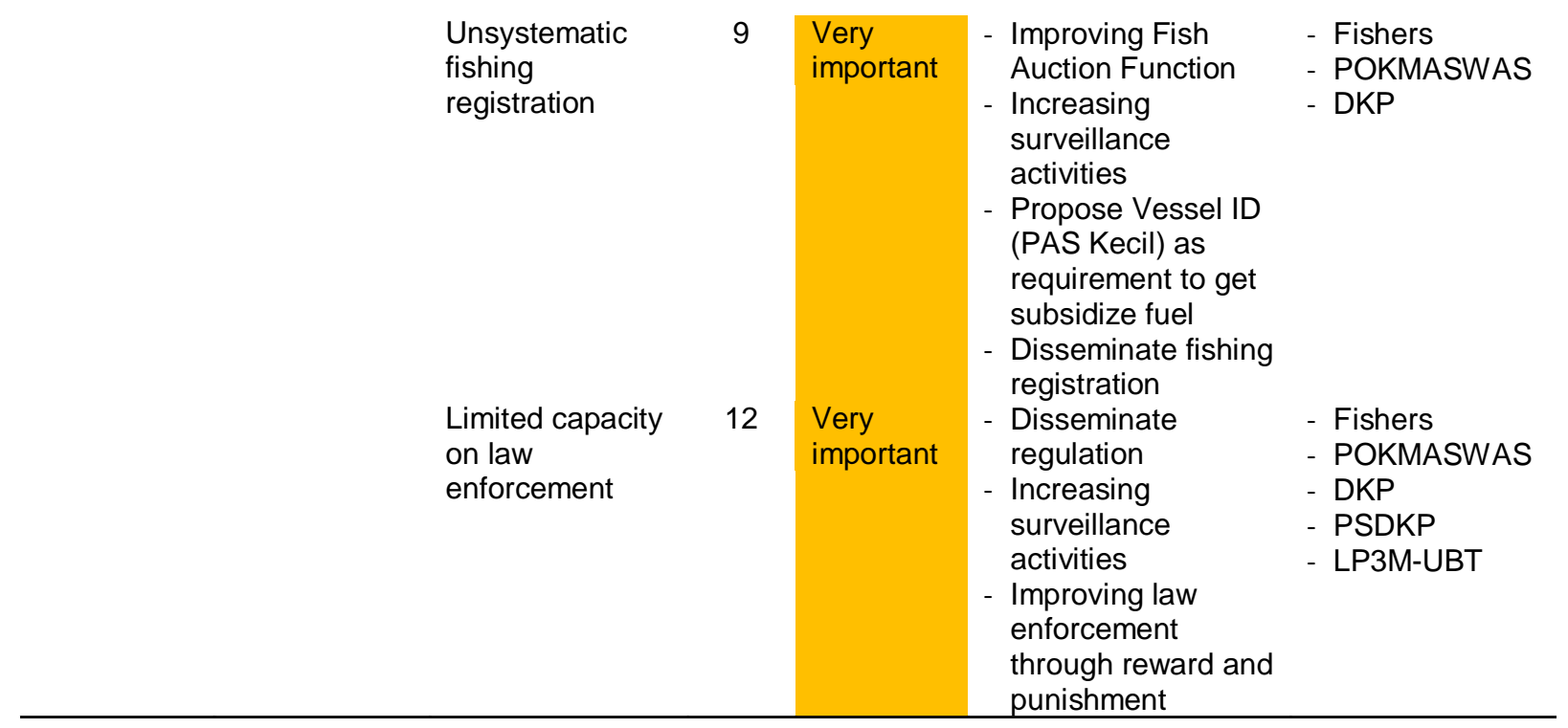

